\section{Lavoisier and the Study of Combustion.}

The Eighteenth Century Revolution in ScienceThe First Phase. By Dr. Andrew Norman Meldrum. Pp. vii +60 . (London, New York and Toronto: Longmans, Green and Co., Ltd., n.d.) $4 s .6 d$.

TWENTY-FIVE years ago the author of this 1 book placed chemical teachers and students under a lasting debt by the publication of an essay on "Avogadro and Dalton"- - a very careful historical and critical discussion of the standing in chemistry of their hypothesis. Incidentally it was shown that many inaccurate statements on the subject were current at the time in the literature presented to students of chemistry, and a real service was done by putting matters in a clear light.

Dr. Meldrum now reappears, handling in the same thorough way a topic of no less interest to students of chemical history - the work of Lavoisier during the four years 1772-75. These years he calls "the first phase" of the revolution effected by Lavoisier, for they culminated in his realisation of the individuality of oxygen, of its place in the atmosphere, and of the part it plays in processes of calcination and combustion. This is, of course, one of the turning-points of chemical history that no teacher or student can disregard. It also marks a region where there has been strife on matters of credit and conduct, with the importation at times of uncomfortable patriotic fervour, and it is one where there was good occasion for Dr. Meldrum to exercise his powers of elucidation.

The book is based mainly on an intensive study of (1) Lavoisier's Memoirs and Journals (so far as the Journals are accessible through Berthelot's "La Révolution chimique-Lavoisier") and (2) Bayen's and Priestley's publications. The result is a historical analysis of great interest and value, which gives the feeling that the author, with a mind sternly braced against the access of prejudice, has got down as deeply into the facts as available materials allow. Until the Lavoisier correspondence is published, it does not seem likely that we shall get more light on the subject.

What Dr. Meldrum has done is to trace out with minute care the course of Lavoisier's thought, experimental work, and publications from the time (1772) when he was seized with the idea that was thenceforth to dominate him. In the sealed note deposited with the Paris Academy of Sciences in November 1773, Lavoisier records his observation of the increase of weight during the combustion of sulphur and phosphorus and the fixation of "an immense quantity of air ". He believes that the same will be found to apply generally to processes of combustion and calcination. The discovery he describes as "appearing to me one of the most interesting of those which have been made since the time of Stahl". How Lavoisier had come to begin his experiments Dr. Meldrum has found no indisputable evidence. He does not mention the view, taken by M. Le Chatelier, that Lavoisier was turned to the study of combustion by having competed in 1766 for an Academy prize on the subject of street lighting. Whatever may have been the stimulus, it is clear the Lavoisier conception of the fixation of air as the general cause of the increase of weight in combustion processes flashed into his mind and became a fixed light that no embarrassments from experiment, no errors in deduction, no hostile criticism could dim.

Dr. Meldrum emphasises again and again the importance of recognising this, in following the course of Lavoisier's work and in trying to understand his relation to those who had been working or were working in the same field. Though at a later date, writing to Joseph Black, he describes himself as having been accustomed to regard Black as his master, there seems no reason to doubt that when Lavoisier made his initial discovery he was unaware of the work of Black, and that he shared abundantly the confusion of mind about gases and the gaseous state that then prevailed and was likely to continue as long as phlogiston held the field. Lavoisier comments on the conspicuous neglect in France of the study of gases. His realisation of the possibility of following processes of gas absorption and gas emission during chemical changes by use of the balance now gave him a fixed principle. When he surveyed the existing records he found only "separate pieces of a great chain". "These authors", he says, "have joined only some links of the chain."

In a memorandum, which Dr. Meldrum gives good reason for dating February 1773, Lavoisier enlarged upon his new ideas and the prospects of discovery which they opened. "The Memorandum ", says Dr. Meldrum, "has a note of exaltation and even of inspiration. Nothing like it can be found in Hales, Black, Cavendish, Priestley, Scheele." It may be judged from this how far our author is from any tendency to under-estimate Lavoisier.

Following upon these preliminaries, we are taken through the record of Lavoisier's progress as detailed in the "Opuscules physiques et chimiques", published in January 1774. This part of Dr.

No. 3186 , VoL. 126] 
Meldrum's book shows him at his best, and it may be strongly commended to those who are concerned with the teaching of the history of science, where the chief difficulty is to get students to orient themselves into the conditions of a past age and the state of earlier thought. The mere reading of the old masterpieces, such as are published in the admirable series of the Alembic Club, does not suffice to free the mind from astonishment that great men should have been so slow to find the way that now seems so plain, and to have made mistakes that now appear so gross. Nothing, perhaps fortunately, is likely to make the student believe that the same sort of thing is happening with the great men of to-day ; but the discussion of Lavoisier's progress, as elucidated by Dr. Meldrum, is as illuminating an example as could be desired of the historian's art applied to scientific discovery.

The concluding chapter of the book is entitled "The Effective Discovery of Oxygen", and here the author is compelled to enter upon the ground where so much controversy has taken place on matters of conduct. We say that Dr. Meldrum has been 'compelled' to enter upon this ground, because it should be clearly understood that the purpose of the book is not controversial. It is to record the history in detail of the first phase of Lavoisier's work-that on combustion-" which led to a revolution in chemistry and even in science", but this necessarily involves particularities relating to the discovery of oxygen.

Dr. Meldrum says in the preface that he presents fresh conclusions on this subject. This does not seem to be quite the right expression, for his 'conclusions' are in essence those which have been reached by others. What Dr. Meldrum does that is fresh is to exhibit in clear detail the course of thought of Priestley and Lavoisier, and to show exactly how Priestley's work helped Lavoisier out of his difficulties.

It is perhaps too much to expect that the book will not be challenged upon its accuracy in some details, and possibly upon some of its conclusions, but we may surely hope that it will not hurt any susceptibilities. On the contrary, it gives a faithful picture of the times and of the confusion of thought on matters that are to-day the schoolboy's elements of chemical knowledge. It shows how easily both discoveries and mistakes of capital importance could be disregarded by the participants, and how far the true history of the modern doctrine of combustion is from being a simple tale that he who runs may read, or one where he can easily apportion praise or blame.

A. Smithells.

\section{High Voltage Cables.}

(1) High Voltage Cables: Theory and Practice of their Design and Operation. By P. Dunsheath. (The Specialists' Series.) Pp. xii +161 . (London: Sir Isaac Pitman and Sons, Ltd., 1929.) 10 s. $6 d$. net.

(2) High Voltage Cables. By L. Emanueli. Pp. vii $+107+9$ plates. (London: Chapman and Hall, Ltd., 1929.) $8 s .6 d$. net.

(1) T T seems quite certain that there will be a great demand for high voltage cable for many years to come. In 1924 the consumption of electric energy per head of the population in Great Britain was 100 units. To-day it is more than 150 units, and it is highly probable that by 1940 it will be three times as large. The saturation point is a long way off, and the effect of reducing the number of the supply stations and increasing their size will be to raise continually the pressure of transmission. The demand for high pressure cables, therefore, will go on increasing.

In the book under review, the author first deals with the economic factors that have to be taken into account in high voltage transmission. $\mathrm{He}$ next discusses the properties of the insulating materials used in the cables. The question of how the dielectric withstands the electric stress applied to it is still uncertain, but there is no uncertainty about the effect of intersheaths in raising the factor of safety of cables. The chapter on belted, screened, and S.L. cables will be very helpful to students as these types of cable are not yet described in the ordinary text-books. There is also a useful chapter on the current rating of cables and the stability of their dielectrics. The thermal resistivity of a dielectric is defined as the difference of degrees Centigrade required to be maintained between the opposite faces of a centimetre cube of the material so that an amount of heat equivalent to an electrical watt may be transferred continu. ously across the cube. This definition or something like it is frequently used by engineering physicists, but it seems to us very clumsy and indefinite. Teachers will doubtless improve it. We prefer Fourier's definition. This book is to be commended.

(2) L. Emanueli is the chief engineer of the Pirelli Cable Works in Italy, and he is well known as one of the leading experts on high voltage cables. $\mathrm{He}$ has continued the excellent work done by Jona, one of his predecessors. At the Milan Exhibition, so far back as 1906, Jona exhibited cable which had successfully withstood a pressure of 150,000 volts for an hour. 